\title{
Do the port health officers at Soekarno-Hatta International Airports and Zainuddin Abdul Madjid International Airports have sufficient knowledge, attitude, and practice regarding emergency landing?
}

\author{
DOI: https://doi.org/10.22435/hsji.v12i1.4026
}

\author{
Herqutanto, ${ }^{1}$ Albert Wijaya, ${ }^{1}$ Budi Sampurna,,${ }^{1,2}$ Manaor F.L. Napitulu ${ }^{1}$, Ferdi Afian ${ }^{1}$ \\ ${ }^{1}$ Department of Community Medicine, Faculty of Medicine, Universitas Indonesia \\ ${ }^{2}$ Department of Forensic Medicine, Faculty of Medicine, Universitas Indonesia
}

Corresponding Author: Albert Wijaya

Email: al.wijaya88@gmail.com

Received: November 2, 2020; Revised: May 3, 2021; Accepted: May 28, 2021.

\begin{abstract}
Background: Emergency landing as an airport emergency requires quick and precise action by Port Health Office (PHO) as the medical coordinator. Medical treatment in an emergency landing is critical for the safety of disaster victims, based on the knowledge, attitudes and behavior of airport PHO officers. This study aimed to determine knowledge, attitude and behavior of PHO officers at Soekarno-Hatta International Airport (SOETTA) and Zainuddin Abdul Majid International Airport (ZAM) regarding emergency landings.
\end{abstract}

Methods: This is an observational study applying cross sectional design. Ninety-eight PHO officers from SOETTA airport and ZAM airport have participated, and their data was collected through questionnaires, and then analyzed based on knowledge, attitude, and practice toward emergency landing.

Results: The knowledge of SOETTA PHO officers was sufficient in $63.5 \%$ officers, while it was $79.2 \%$ in ZAM. SOETTA PHO officers' attitude was positive in $67.6 \%$ while in ZAM it was $54.16 \%$. The behavior of SOETTA PHO officers was good in $55.4 \%$ officers while in ZAM it was $75 \%$.

Conclusion: The level of knowledge of SOETTA and ZAM PHO officers regarding emergency landings was sufficient. The attitude of SOETTA and ZAM PHO officers regarding emergency landings was positive. The behavior of SOETTA and ZAM PHO officers was good for emergency landings. (Health Science Journal of Indonesia 2021;12(1):33-38)

Keywords: emergency landing, port health office, knowledge, attitudes and practice

\begin{abstract}
Abstrak
Latar belakang: Emergency landing sebagai salah satu keadaan darurat bandara memerlukan tindakan yang cepat dan tepat oleh Kantor Kesehatan Pelabuhan (KKP) sebagai koordinator medis. Penanganan medis dalam emergency landing sangat menentukan keselamatan dan keamanan korban, yang berbasis pada pengetahuan, sikap dan perilaku petugas KKP bandara. Penelitian ini bertujuan untuk mengetahui tingkat pengetahuan, sikap dan perilaku petugas KKP Bandara Internasional Soekarno-Hatta (SOETTA) dan Bandara Internasional Zainuddin Abdul Majid (ZAM) terhadap emergency landing.
\end{abstract}

Metode: Penelitian ini adalah sebuah studi obervasional dengan disain potong lintang. Sembilan puluh delapan petugas KKP dari 74 bandara SOETTA dan 24 bandara ZAM diambil datanya lewat kuesioner. dan selanjutnya dinilai pengetahuan, sikap dan perilaku terhadap emergency landing.

Hasil: Sebanyak $63,5 \%$ petugas KKP SOETTA memiliki pengetahuan yang cukup sementara 79,2\% petugas ZAM meiliki pengetahuan yang tergolong cukup. Untuk hasil sikap petugas KPP SOETTA yang tergolong positif $67,6 \%$ sementara di ZAM sikap petugas KPP yang tergolong positif 54,16\%. Untuk hasil perilaku petugas KPP SOETTA yang tergolong baik 55,4\% sementara di ZAM perilaku petugas KPP yang tergolong baik 75\%.

Kesimpulan: Tingkat pengetahuan petugas KKP SOETTA dan petugas KKP ZAM terhadap emergency landing tergolong cukup. Sikap petugas KKP SOETTA dan ZAM terhadap penanganan emergency landing positif. Perilaku petugas KKP SOETTA dan ZAM cukup baik terhadap emergency landing. (Health Science Journal of Indonesia 2021;12(1):33-38)

Kata kunci: emergency landing; petugas KKP; pengetahuan, sikap dan perilaku 
Emergency landing is one of airport emergencies that range from an imminent threat to safety and operation of the aircraft to the sudden need for passengers or crew to land immediately on the ground such as a medical emergency. ${ }^{1-2}$ In emergency landing, fast and proper medical response is required by Port Health Office (PHO) officers. According to the Federal Emergency Management Agency (FEMA), prompt and proper action in emergency management is the state of being prepared and ready to respond to a disaster, crisis, or other types of emergency situations. ${ }^{3}$ This vital capacity is built through planning and training. Therefore, a systematic approach should be applied to the management of emergency as a whole, and in particular in determining the necessary steps. 4,5 In Indonesia, recent case of emergency landing occurred on October 1st, 2019 by an Emirates Airline travelling on the Dubai-Auckland which experienced turbulence. The aircraft was forced to make an emergency landing at Ngurah Rai Airport, Denpasar, Bali. A total of 11 passengers were reported injured as a result of the incident and received treatment at the airport health port office, and 2 people were referred to BIMC KUTA Hospital. ${ }^{6}$

Every airport is required to have an Airport Emergency Plan (AEP) document to handle Emergency landing. In the process of making the AEP, airport administrators are required to coordinate with the Airport Emergency Committee (AEC). The PHO officers as an AEC during an emergency has duties to go to the emergency scene by ambulance, and act as a coordinator of medical activities. Medical treatment in emergency landing greatly determines the safety and security of the victim. This medical treatment is based on the knowledge, attitudes and behavior of PHO officers. ${ }^{7-10}$

Research conducted by Ezreqat et al (2017) at Saudi Arabia airport medical team to assess the knowledge, attitudes and behavior of medical teams towards disasters at airports such as Mass Casualty Incidents (MCI), found that the airport medical team as a whole had a high level of knowledge and good attitude towards MCI.

While there is no other research about airport medical team knowledge, attitudes and behavior regarding emergency preparedness, there is similar research conducted by Adenekan et al (2016) that showed the significance of knowledge, attitudes and behavior of medical teams regarding emergency preparedness in hospital.There was an overall deficiency in the respondent knowledge of emergency preparedness.
Their attitude was good and acceptable, but their practices in terms of the frequency of emergency drills and the frequency of regularly updating the emergency plans were grossly inadequate.

Until now there is no research yet that has been conducted to assess the knowledge, attitudes and behavior of PHO officers regarding emergency landings in Indonesia. This study aimed to determine the level of knowledge, attitudes and behavior of PHO officers at Soekarno-Hatta (SOETTA) International Airport in Jakarta and Zainuddin Abdul Majid (ZAM) International Airport in Lombok, West Nusa Tenggara Province, regarding emergency landings.

\section{METHODS}

This is an observational study applying crosssectional design to determine the knowledge, attitudes and behavior of PHO officers at SOETTA and ZAM regarding emergency landings. SoekarnoHatta International Airport was choosen for observation, because it is the busiest international airport at Indonesia in relation as the main entrance to the Indonesian state. There are also an emergency landing occurred at SOETTA on 04 May 2012 because it needed medical assistance and resulted in the death of the passenger. ${ }^{11}$ Zainuddin Abdul Majid International Airport (ZAM) was choosen based on data from the Statistics Indonesia (BPS), as an international airport in Lombok with the largest increase in foreign tourist visits from year to year (year of year / YoY) mounting to $2.94 \%{ }^{12}$

The study was conducted in February 2020 using written questionnaires. The questionnaires were distributed at the airport's Port Health Office. There was a total of 98 subjects consisting of 74 subjects at SOETTA International Airport and 24 subjects at ZAM International Airport. The sample size for this study was calculated using sample size calculator to detect a significant difference between two proportions (https://epitools.ausvet.com.au/twoproportions). Considering there is no research data about the proportion of knowledge, attitudes and behavior of PHO officers, this study used the assumption of a good proportion at SOETTA Airport of $70 \%$ and the proportion of good knowledge, attitude and behavior at ZAM Airport by $30 \%$. Using the formula of the calculation, minimum sample proportion needed for SOETTA airport was 60 subjects and ZAM airport 18 subjects. Thus the sample in this study has exceeded of the minimum sample. 
The instrument used in this study was developed based on a questionnaire used in evaluating knowledge, attitudes and behavior regarding emergency situations. This questionnaire has been used by medical workers at airports in Saudi Arabia and hospitals in Africa. ${ }^{13-14}$

As an instrument of process for validation, the questionnaire was tested on PHO officers at equivalent International airport; i.e. Halim Perdana Kusuma International Airport in Jakarta. The questionnaire was filled in by $10 \mathrm{PHO}$ officers who were involved in handling the emergency situation, represented by doctors, epidemiologists, nurses and ambulance drivers.

After the trial test, the questionnaire was evaluated and revised with the help of expert (Head of SOETTA KKP, Aerospace medicine specialist) for use in evaluating the knowledge, attitudes and behavior of SOETTA and ZAM PHO officers.

The final questionnaire consist of four different sections. In the first part, respondents were asked about their demographic data. Sections two to four discussed the knowledge, attitude and practice of the PHO officers regarding emergency landings. There are ten questions in each section. Questions about knowledge is include knowledge itself on aircraft type, coordination during emergency landing, location of decision, also priority of victims. For questions on attitudes, we asked the repondents agreement on different statements: whether health port an organization responsible for safety emergency landing, revisions to the Airport Emergency Plan are carried out periodically, where every PHO officers must know the airport emergency response plan. In terms of practice, respondents were asked to remember whether they had experience in emergency landing, had attended emergency landing simulation training, and participated in managing the emergency response medical team.

Research data that have been collected were analyzed descriptively. Measurement of the level of knowledge about emergency landing was obtained from 10 questions. Since there is no standard were available, the research team reached a consensus that if the answer to the questionnaire given was $\geq 80 \%$ correct, then it was categorized as "sufficient" and if it was $<80 \%$ is categorized as "insufficient". An attitude measure using 10 questions about attitudes regarding emergency landings was used. If the answer to the questionnaire given was $\geq 80 \%$ correct, then it was categorized as "positive" and if it was $<80 \%$ correct, then categorized as "negative". The behavior measurement is using 10 questions about behavior regarding emergency landing. The behavior measurement used 10 questions about behavior regarding emergency landing. If the answer was $\geq 80 \%$ was correct, it was categorized as "good" behavior, and if it was $<80 \%$ then categorized as "poor". Data analysis was performed using SPSS version 23. This research had been approved by the Ethics Committee of the Faculty of Medicine Universitas Indonesia with letter number: KET-10/ UN2.F1/ETIK/PPM.00.02/2019.

\section{RESULTS}

Characteristics of respondents as follow: respondents in SOETTA were mostly women, while in ZAM, there were more male workers; most respondents were in the 25-45 years age group both in SOETTA and ZAM, with the mean age of port health officer in SOETTA were 41.6 years and in the ZAM 37.8 years; most respondents completed senior high school or completed higher education at both airports.

The results showed that both airports had the fewest percentage in medical work unit which compared to non-medic and paramedic. Most PHO officers at both airports have worked for more than 7 years and have received airport emergency training. The average lenght of work of PHO officers at SOETTA is 13.9 years, while in ZAM it is 12.8 years.

Table 1. Characteristic of the respondents $(\mathrm{n}=98)$

\begin{tabular}{|c|c|c|}
\hline Characteristic & $\begin{array}{c}\text { SOETTA } \\
\mathrm{n}(\%)\end{array}$ & $\begin{array}{l}\text { ZAM } \\
\text { n (\%) }\end{array}$ \\
\hline \multicolumn{3}{|l|}{ 1. Sex } \\
\hline Male & $33(44.6 \%)$ & $14(58.3 \%)$ \\
\hline Female & $41(55.4 \%)$ & $10(41.7 \%)$ \\
\hline \multicolumn{3}{|l|}{ 2. Age } \\
\hline$<25$ years & $3(4.1 \%)$ & $3(12.5 \%)$ \\
\hline $25-45$ years & $45(60.8 \%)$ & $17(70.8 \%)$ \\
\hline$>45$ years & $26(35.1 \%)$ & $4(16.7 \%)$ \\
\hline \multicolumn{3}{|l|}{ 3. Education } \\
\hline$\leq$ Senior high school & $5(6.8 \%)$ & $2(8.3 \%)$ \\
\hline$>$ Senior high school & $69(93.2 \%)$ & $22(91.7 \%)$ \\
\hline \multicolumn{3}{|l|}{ 4. Work unit } \\
\hline Medic & $18(24.3 \%)$ & $2(8.3 \%)$ \\
\hline Paramedic & $22(29.7 \%)$ & $13(54.2 \%)$ \\
\hline Non-medic & $34(46 \%)$ & $9(37.5 \%)$ \\
\hline \multicolumn{3}{|l|}{ 5. Length of work } \\
\hline$\leq 7$ years & $20(27 \%)$ & $6(25 \%)$ \\
\hline$>7$ years & $54(73 \%)$ & $18(75 \%)$ \\
\hline \multicolumn{3}{|l|}{ 6. Training } \\
\hline Yes & $41(55.4 \%)$ & $18(75 \%)$ \\
\hline No & $33(44.6 \%)$ & $6(25 \%)$ \\
\hline
\end{tabular}


Generally, respondents at both airports had sufficient level of knowledge, with $63.5 \%$ of SOETTA PHO officers had sufficient knowledge, while in ZAM, is $79.2 \%$ PHO officers had sufficient knowledge.

Table 2. Knowledge of respondents towards emergency landing

\begin{tabular}{cccc}
\hline \multirow{2}{*}{ Airport } & \multicolumn{2}{c}{ Knowledge } & \multirow{2}{*}{ Total } \\
\cline { 2 - 3 } & Sufficient (\%) & Insufficient (\%) & \\
\hline SOETTA & $47(63,5 \%)$ & $27(36,5 \%)$ & 74 \\
ZAM & $19(79,2 \%)$ & $5(20,8 \%)$ & 24 \\
\hline Total & $66(79,2 \%)$ & $32(20,8 \%)$ & 98 \\
\hline
\end{tabular}

The attitude of SOETTA PHO officers was $67.6 \%$ positive, while in ZAM the attitude of port health officers was $54.16 \%$ positive. Thus, in general SOETTA Airport and ZAM Airport PHO officers had more positive attitude $(64.28 \%)$ than negative attitude (35.72\%). (Table 3)

Table 3. Attitudes of respondents towards emergency landing

\begin{tabular}{cccc}
\hline \multirow{2}{*}{ Airport } & \multicolumn{2}{c}{ Attitude } & \multirow{2}{*}{ Total } \\
\cline { 2 - 3 } & Positive $(\%)$ & Negative $(\%)$ & \\
\hline SOETTA & $50(67,6 \%)$ & $24(32,4 \%)$ & 74 \\
ZAM & $13(54,16 \%)$ & $11(45,84 \%)$ & 24 \\
\hline Total & $63(64,28 \%)$ & $35(35,72 \%)$ & 98 \\
\hline
\end{tabular}

This study indicates that the practices of SOETTA PHO officer was good in $55.4 \%$ respondents while in ZAM, $75 \%$ of PHO officers practices was classified as good. Thus, in general SOETTA Airport and ZAM Airport officers had good practice (60.20\%) than poor $(39.80 \%)$. (Table 4$)$

Table 4. Practices of respondents towards emergency landing

\begin{tabular}{cccc}
\hline \multirow{2}{*}{ Airport } & \multicolumn{2}{c}{ Practices } & \multirow{2}{*}{ Total } \\
\cline { 2 - 3 } & Good $(\%)$ & Poor $(\%)$ & \\
\hline SOETTA & $41(55,4 \%)$ & $33(44,6 \%)$ & 74 \\
ZAM & $18(75 \%)$ & $6(25 \%)$ & 24 \\
\hline Total & $59(60,20 \%)$ & $39(39,80 \%)$ & 98 \\
\hline
\end{tabular}

\section{DISCUSSIONS}

This research had discover a different situation, where more respondents at ZAM International Airport were men, while SOETTA International Airport have more women as the officers. Same case is found in a study who conducted by Ezreqat et al (2017) at Saudi Arabia airport medical team, where also found that there were more male workers. This situation might be happen because due to general culture about this duty is for male, especially since the characteristic of duty is spend more working hours at the airport, which may not be suitable for female workers. ${ }^{12}$

Based on the group of age, more respondents both airports were in 25-45 years old. The average age of respondents in this study was 41.6 years old at SOETTA and 37.8 years old at ZAM. Research by Ezreqat et al (2017) at Saudi Arabia airport medical team were found an average age of health workers on 36 years old. Respondents in this age group are in the best condition to receive the training in airport emergency handling, due to mature emotions and sufficient length of work since recruitment.

Educational characteristics of the respondents from the two airports showed that they mostly completed high school or higher. It has the same line with research by Ezreqat et al (2017), which only 14.7\% have high school education and the remaining $85.3 \%$ have education above senior high school. This is significant with the phenomenon of demands in the health sector which requires a minimum formal education of a diploma or bachelor's degree in health.

Medical personnel and paramedics at both airports had the largest number, which $54.05 \%$ at SOETTA and $62.5 \%$ at ZAM. This result is similar with research who conducted by Ezreqat et al (2017) Saudi Arabia airport medical team $85.4 \%$ consisting of medical and paramedical. This is in line with the duties of the port health office engaged in the health sector. Meanwhile, PHO officers mostly have worked more than 7 years at both airports. The reason for this is because PHO officers were usually civil servants who worked in accordance with their assignments at the port health office. ${ }^{13}$

The results also shows that most of PHO officers had received airport emergency training. Supposedly all PHO officers have received training, so there was a gap for this condition. This could be because the training was not available every time (monthly/ yearly) so when it was time for the training, the officers were unable to attend.

The results of the research for respondents' knowledge of emergency landing at both airports were sufficient. Majority of respondents (63.5\% SOETTA, $79.2 \%$ ZAM) already had sufficient knowledge. This is similar to a study by Ezreqat et al (2017) which found that $64.7 \%$ of health workers at Saudi Arabia airports have sufficient knowledge of Mass Casualty Incidents (MCI). The results of the 
respondent's attitude towards handling emergency landing showed more positive attitudes, namely $67.6 \%$ at SOETTA and $54.2 \%$ at ZAM.

The research by Adenekan et al (2016) has assessed the knowledge, attitudes and practices of emergency medical officers in handling emergencies in hospitals. It found that $93.2 \%$ of respondents had a positive attitude towards handling emergencies in the hospital. Health workers believe they need to understand the emergency plan; emergency plan must be updated regularly; simulated drill exercises should be done frequently in the hospital. This is in line with the positive attitude of most $\mathrm{PHO}$ officers at both airports who agreed that the AEP revision should be carried out periodically. Drills (simulation exercises) is also must be carried out at the airport, with every PHO officer must know the airport emergency response plan. This thing could be interesting because PHO officers who have a positive attitude will encourage rapid response to emergencies, and when there is a spike in cases it can be adequately managed without causing chaos to the ongoing emergency response system. ${ }^{13-14}$

Overall respondent practices towards handling emergency landing were also good at both airports, $55.4 \%$ at SOETTA and $75 \%$ at ZAM respectively. These results were same as what it found on the knowledge and attitudes of PHO officers at both airports, the majority of which had sufficient knowledge and positive attitudes regarding emergency landings.

When compared to research by Adenekan et al (2016,) it was found that the practices of health workers in the hospital was still insufficient, this was due to a lack of emergency training or insufficient information that there would be training so that officers were not involved in it. Research by Moabi (2009) on the knowledge, attitude and behavior of health workers in hospitals in Africa towards disaster preparedness also found that the behavior of health workers was insufficient due to the lack of emergency simulation training. ${ }^{15}$

This study has several limitations. Fist the method used is a cross-sectional design with a selfadministered questionnaire as an instrument. The limited time allocation can lead to the possibility that imperfections in filling out the questionnaire can also occur. Another limitation of the study is the possibility of information bias that comes from assessing respondent attitudes and practices. This arises because it relies heavily on filling anonymous questionnaires, thus relying on the honesty of respondents when filling in research data.
In addition, there are limitations due to the way of assessing attitudes and practices that is supposed to use the Objective Structured Clinical Examination (OSCE) method. Actually, the use of the word skill is more precise than practices, but because in this study it was not possible to measure skills, an assessment was made of the practices of officers in dealing with emergency landing.

In conclusion, the level of knowledge of PHO officers at SOETTA International Airport and ZAM International Airport on emergency landing are mostly sufficient. Most of the respondent's attitude towards handling emergency landing shows a positive attitude at SOETTA International Airport and at ZAM International Airport, also for the practices of the PHO officers at SOETTA International Airport and at ZAM International Airport mostly shows that they were good for the emergency landing. From this result, we can expect PHO officers at both airports to be ready and prepared regarding emergency landings.

\section{REFERENCES}

1. Ministry of Transportation. Pedoman penyusunan dokumen rencana penanggulangan keadaan darurat di Bandar Udara. Jakarta: The Institute; 2016. Indonesian.

2. United States. Department of Transportation. Airport emergency plan. Maryland: The Institute; 2010.

3. United States Department of Homeland Security. Federal Emergency Management Agency (FEMA). The four phases of emergency management. Washington D.C: The Institute; 2010.

4. Ministry of Transportation. Petunjuk teknis pengawasan rencana penanggulangan Keadaan Darurat Bandar Udara (Airport Emergency Plan) dan Pertolongan Kecelakaan Penerbangan dan Pemadam Kebakaran (PKP-PK). Jakarta: The Institute; 2017. Indonesian.

5. Ministry of Transportation. Standar teknis dan operasional peraturan keselamatan penerbangan sipil. Jakarta: The Institute; 2019. Indonesian.

6. Rosidin I. Pesawat Emirates berpenumpang 326 orang alamiturbulensi,11 penumpangterluka.Kompas[Internet] 2019 Oct 01. [cited 2019 Dec 10]. Available from: https:// denpasar.kompas.com/read/2019/10/01/21412021/ pesawat-emiratesberpenumpang-326-orang-alamiturbulensi-11-penumpang?page $=$ all .

7. ICAO. Aerodrome design and operations 8th edition. Montreal Canada: The Institute; 2018.

8. ACI World Safety and Technical Standing Committee. Emergency preparedness and contingency planning handbook. Montreal Canada: The Institute; 2014. 
9. Ministry of Transportation. Peraturan keselamatan penerbangan sipil. Jakarta: The Institute; 2017. Indonesian.

10. Minnesota Airport Technical Assistance Program. Emergency guidebook for general aviation airports. Minnesota United States: The Institute; 2015.

11. Subiantoro R. Mengenang super jumbo airbus A380 yang pernah landing di RI. CNBC [Internet] 2018 July 04. [cited 2019 Dec 10]. Available from: https:// www.cnbcindonesia.com/news/20180704152514-421930/mengenangsuper-jumbo-airbus-a380-yangpernah-landing-di-ri. Indonesian.

12. Sembiring L. Naik tipis, 1,56 juta turis asing sambangi RI di Agustus 2019. CNBC [Internet]. 2019 Oct 01 [cited 2019 Dec 10]. Available from: https:// www.cnbcindonesia.com/news/20191001135730-4103530/naik-tipis-156-juta-turis-asing-sambangi-ridi-agustus-2019. Indonesian.

13. Ezreqat S. Evaluation of a Saudi Major Airport's medical preparedness for mass casualty incident: a mixed-methodology study. MOJ Public Health. 2017.

14. Adenekan B, Balogun M, Inem V. Knowledge, attitude, and practices of emergency health workers toward emergency preparedness and management in two hospitals in Lagos. Journal of Clinical Sciences. 2016;13(1):23.

15. R. M. Moabi (2008). Knowledge, attitudes and practices of health care workers regarding disaster Preparedness at Johannesburg Hospital in Gauteng Province, South Africa [master thesis]. Johannesburg: University of the Witwatersrand; 2009. 